\title{
Chemical and in vitro evaluation of Leucaena (Leucaena leucocephala) Leaves as a Substitute of Alfalfa (Medicago sativa L.) with/without Rejected Green Banana Fruits (Musa paradisiaca)
} \author{
Sobhy Mohamed Abdallah Sallam ${ }^{4}$, Yosra Ahmed Soltan ${ }^{4}$, and Wafaa Mostafa Ali Ghoneem ${ }^{2}$ \\ ${ }^{I}$ Regional Center for Food and Feed, Agricultural Research Center, Giza 12619, Egypt \\ ${ }^{2}$ Animal Production Department, Faculty of Agriculture, Cairo University, Giza 12613, Egypt \\ ${ }^{3}$ INRAE, UR143, Unite de Recherches Zootechnique, Guadeloupe 97170, France \\ ${ }^{4}$ Animal and Fish Production Department, Faculty of Agriculture, Alexandria University, Alexandria 21526, Egypt \\ *Corresponding author's Email: mohamed.rashid@arc.sci.eg; (DORCiD: 0000-0003-2827-7290
}

Mohamed Rashid Salama Rashid ${ }^{1,2 *}$, Mohamed Ahmed Hanafy ${ }^{2}$, Mervat Sayed Hassan Youssef ${ }^{1}$, Harry Archimède $^{3}$,

\begin{abstract}
Leucaena leaves and rejected green banana fruits can be promising to cope with feed gaps in arid and semi-arid Mediterranean regions. The present study evaluated the feeding value and secondary active compounds of Leucaena leaves and rejected green banana fruits for ruminants using a semi-automated gas production (GP) system. Comparisons were made with the traditional feeds as alfalfa, and Dichanthium spp. grass hay. Analysis of HPLC was performed for the feed ingredients to characterize the main phenolic components. The in vitro evaluation was carried out for the experimental feed ingredients and diets. Four diets were formulated as the first diet consisted of alfalfa and grass hay at a ratio of 35:65 (AG), the second diet composed of alfalfa, grass hay, and green banana fruits at a ratio of 35:55:10 (AGB), third and fourth diets were prepared by replacing alfalfa in AG and AGB with Leucaena leaves to be LG and LGB, respectively. Leucaena leaves showed a high content of valuable phenolic components that have antioxidant and anti-inflammatory properties, such as gallic acid, ellagic acid, and naringenin Moreover, Leucaena leaves and diet had higher crude protein, total phenols, and total tannins than alfalfa, which was reflected on the chemical composition of diets, and recorded the lowest total accumulative GP at 24 hours leading to low $\mathrm{CH}_{4}$ and $\mathrm{CO}_{2}$ production. Banana fruits recorded the lowest ruminal $\mathrm{pH}$, ammonia concentration, and degraded neutral detergent fiber, compared to other feed ingredients, while it had the highest GP and degraded organic matter. Therefore, it is highly recommended to use Leucaena leaves in animals' diets with/without rejected green banana fruits as an alternative feed resource with potential environmental and animal health benefits.
\end{abstract}

Keywords: Alfalfa, Dichanthium spp. grass, Green banana fruits, In vitro evaluation, Leucaena leucocephala leaves, Phenolic compounds

\section{INTRODUCTION}

Livestock production is predominantly maintained on forage plants and agriculture by-products in most aired and semiarid Mediterranean lands. These forages are characterized by high fiber content and a low percent of crude protein (CP). Shrub legumes have been shown to enhance the protein supply of ruminants in these regions. For example, Leucaena (Leucaena leucocephala) is concerned as one of the most promising legumes that possess a high-quality protein and contain various valuable secondary metabolites, such as tannins, flavonoids, saponins, alkaloids, cardiac glycosides, and glycosides. Therefore, Leucaena leaves are valuable feed resources with potential health benefits for ruminants (Xu et al., 2018). Among these bioactive compounds, Leucaena tannins have received significant attention focusing on ruminant production response (Morales and Ungerfeld, 2015; Huang et al., 2018). Low to moderate condensed tannins (CT) of Leucaena can alter the rumen fermentation profile and decrease CP degradation. Forage with high nitrogen sources has to be associated with suitable fermentable carbohydrates to obtain optimal ruminal microbial fermentation and nutrient degradability (Salama et al., 2020).

The rejected green banana fruits (Musa paradisiaca) are an agriculture by-product found in abundance in the Mediterranean. It is a rich source of carbohydrates and sugars, mainly sucrose, glucose, and fructose. Although bananas provide energy due to the presence of starch, they are low in crude fiber, CP, and mineral contents (Kramer, 2014). Babatunde (1992) estimated that 30 to $40 \%$ of the total banana production is non-marketable (rejected banana fruits) because of failure to meet quality standards, making them potentially available for livestock feeding. The organic matter (OM) degradability and digestibility of the banana fruits are found to be 628 and $783 \mathrm{~g} \mathrm{~kg}^{-1} \mathrm{DM}$, respectively, when the nutritional value is assessed in goats (Pieltain et al., 1998). Rashid et al. (2019) stated that there was no depression effect on animal performance when $1 \mathrm{~kg}$ of fresh rejected banana fruits was used in diets of lactating ewes. Green banana fruits also may have bioactive components (e.g., phenolic) that may affect the ruminal fermentation profile and degradability. It was hypothesized that the association between carbohydrates in rejected green banana fruits and CP in Leucaena 
leaves would accelerate ruminal fermentation, microbial activity, and nutrient utilization. The effects of the combination of the secondary metabolites naturally found in both plant sources are not known. Therefore, the current study aimed to monitor the main phenolic components of the tested feed ingredients by HPLC and evaluate the replacing effects of alfalfa in a basal ration of tropical grass hay with Leucaena leaves with or without rejected green banana fruits on in vitro nutrients degradability, fermentation parameters, and changes in rumen protozoa population.

\section{MATERIALS AND METHODS}

\section{Place of study}

The current study was performed in cooperation between INRAE, UR143, Unite de Recherches Zootechnique, Guadeloupe, France, and Animal Production Department, Faculty of Agriculture, Cairo University, Egypt. The in vitro experiment was performed at the advanced laboratory of animal nutrition of the Department of Animal and Fish Production, Faculty of Agriculture, Alexandria University, Egypt.

\section{Ethical approval}

The experimental procedures and protocols have been performed under the guidelines of the EU Directive number 63 in 2010 and the Council of 22 September 2010 for animals that when used for scientific purposes.

\section{Experimental feed ingredients and diets}

The experimental feed ingredients were collected from Guadeloupe, French West Indies (Guadeloupe, latitude 16.16 $\mathrm{N}$, longitude $61.30 \mathrm{~W}$ ). The grass hay came from natural grassland in Basse-Terre, west Guadeloupe, with irrigation and mineral fertilization of $100 \mathrm{~kg}$ of N/ha/year. The hay was based on tropical grass (Dichanthium spp.) aged around 75 days old. Leucaena leaves were collected manually from fallow farmland in Grande-Terre, northeast Guadeloupe. All leaves were wilted and dried in a shadow place $\left(30^{\circ} \mathrm{C}\right)$ for 7 days with daily overturn. Rejected green banana fruits (damaged, under- or over-sized) were obtained from a banana commercial French farm then chopped and dried in the oven at $50^{\circ} \mathrm{C}$ for 72 hours. All feed ingredients were crumbled into small particles then milled through a $1 \mathrm{~mm}$ screen before using. Four experimental diets were prepared as the first diet consisted of alfalfa and grass hay at a ratio of 35:65 (AG), second diet entailed alfalfa, grass hay, and green banana fruits at a ratio of 35:55:10 (AGB), third fourth diets were prepared by replacing alfalfa in AG and AGB with leucaena leaves to be LG and LGB, respectively. The diets were formulated to meet NRC requirements for growing small ruminants (NRC, 2007).

\section{Chemical analysis of feed ingredients}

The experimental feed ingredients were chemically analyzed according to AOAC (AOAC, 2000) for dry matter (DM) content by oven-drying to a constant weight at $60^{\circ} \mathrm{C}$, ash content determined by burning feeds samples at $550^{\circ} \mathrm{C}$ for 4 hours, $\mathrm{CP}$ by Kjeldahl procedure $(\mathrm{N} \times 6.25)$, and ether extract $(\mathrm{EE})$ using an automated Soxtec apparatus (Soxtec $^{\mathrm{TM}} 2050$, Foss, Höganäs, Sweden). Contents of neutral detergent fiber (NDF), acid detergent fiber (ADF), and acid detergent lignin (ADL) were sequentially measured using the ANKOM ${ }^{\text {DELTA }}$ Automated Fiber Analyzer with pump system (ANKOM, model DELTA, Macedon NY, USA) in a fiber filter bag 25-micron porosity F57 ANKOM). Total phenols (TP) content (ascorbic acid equivalents) in feed ingredients were determined according to the FolinCiocalteureagent method (Makkar, 2003). Total tannins (TT) were estimated when $5 \mathrm{~g}$ of the sample was boiled in water for $30 \mathrm{~min}$ then centrifuged at $2000 \mathrm{rpm}$ for $20 \mathrm{~min}$. Then, one $\mathrm{ml}$ of the sample extract was added to $75 \mathrm{ml}$ water then 5 $\mathrm{ml}$ of Folin-Denis reagent, and $10 \mathrm{ml}$ of sodium carbonate solution were added. The sample absorbance was read using a spectrophotometer (Quimis ${ }^{\circledR}$, Diadema, Brazil) at $700 \mathrm{~nm}$ after $30 \mathrm{~min}$ and tannic acid was used as standard. The TT content of the samples as a percentage was obtained from the standard graph of tannic acid (Katoch, 2011).

\section{Phenolic compounds quantitative analysis}

High-Performance Liquid Chromatography (HPLC, Agilent 1260 series Santa Clara, USA) was carried out to identify the phenolic compounds excited in the experimental plant samples. The separation was carried out using the Eclipse C18 column ( $4.6 \mathrm{~mm}$ x $250 \mathrm{~mm}$ i.d., $5 \mu \mathrm{m}$ ). The mobile phase consisted of water (A) and $0.05 \%$ tri-fluoro-acetic acid in acetonitrile (B) at a flow rate of $1 \mathrm{ml} / \mathrm{min}$. The mobile phase was programmed consecutively in a linear gradient as follows: $0 \mathrm{~min}(82 \% \mathrm{~A}), 0-5 \mathrm{~min}(80 \% \mathrm{~A}), 5-8 \mathrm{~min}(60 \% \mathrm{~A}), 8-12 \min (60 \% \mathrm{~A}), 12-15 \min (82 \% \mathrm{~A}), 15-16 \mathrm{~min}$ $(82 \% \mathrm{~A})$, and 16-20 (82\%A). The multi-wavelength detector was monitored at $280 \mathrm{~nm}$. The injection volume was $5 \mu 1$ for each of the feed samples ethanolic solution. The column temperature was maintained at $40^{\circ} \mathrm{C}$. The analytical curve was prepared by dilutions of 17 analytical phenolic standards ( $\geq 95 \%$ purity HPLC grade, from Sigma-Aldrich® Brand (Santa Louis, USA). 


\section{In vitro gas production assay}

The experimental feed ingredients and diets were evaluated using the semi-automatic gas production system, which is equipped with a pressure transducer and a data logger (Pressure Press Data GN200, Sao Paulo, Brazil) according to Bueno et al. (2005) and modified by Soltan et al. (2018). Ruminal contents from four healthy fasted slaughtered buffalo bulls (Bubalus bubalis) with an average live weight of $500 \pm 10 \mathrm{~kg}$ SE were obtained individually at the slaughterhouse of the Agricultural Experimental Station of the Faculty of Agriculture, Alexandria University, Egypt. The animals were fed a diet with a 40:60 roughage: concentrate ratio, clover hay as a roughage source, and commercial concentrate fed mixture (152 CP g/kg DM). The ruminal contents were collected as described by Sabry et al. (2021).

The $\mathrm{pH}$ of the ruminal fluid for animals was measured using a portable $\mathrm{pH}$ meter (GLP 21 model; CRISON INSTRUMENTS, Barcelona, Spain). The collected ruminal fluid was blended for 10 seconds, squeezed through 4 layers of cheesecloth, and the temperature was kept at $39^{\circ} \mathrm{C}$ under $\mathrm{CO}_{2}$. The nutritive buffer incubation medium was prepared according to Onodera and Henderson (1980) and used to dilute the squeezed rumen fluid with a 1:2 ratio (rumen: buffer) to prepare the buffered ruminal inoculum (BRI). A dried ground (1 mm screen) sample of $500 \mathrm{mg}$ for all the experimental feed ingredients and diets were weighed (with 8 repetitions) in $120 \mathrm{ml}$ volume dark glass bottles, then 45 $\mathrm{ml}$ of BRI were added into the bottles and has been shaken well. To obtain the net values of GP, blank bottles were prepared with $45 \mathrm{ml}$ BRI without substrate. Moreover, Berseem clover (Trifolium alexandrinum L.) hay was used as an internal standard to detect the sensitivity changes induced by the BRI (Soltan et al., 2013). Instantly, after BRI addition, all bottles were locked tight with $20 \mathrm{~mm}$ butyl septum stoppers and incubated at $39^{\circ} \mathrm{C}$ in a forced-air oven (FLAC STFN 52 Lt, Treviglio, (Italy) for 48 hours. The head space gas pressure was recorded at 4, 8, 12, 24, and 48 hours after the incubation start time to calculate the net produced gas volumes. After each gas sampling, the incubated bottles were vented, handily shaken, and returned to the incubator (Soltan et al., 2013).

\section{In vitro ruminal nutrient degradability, fermentation parameters, and protozoal count}

All the incubation bottles were removed from the incubator after 48 hours and placed directly on an ice bath to inhibit fermentation. After bottle opening, the ruminal final $\mathrm{pH}$ values were determined by the same portable $\mathrm{pH}$ meter which used before. The truly degraded OM was analyzed according to Blümmel et al. (1997). The bottle's residuals (nondegraded contents) were filtered in pre-weighed free crucibles, washed with hot distilled water, then dried, and allowed to burn into ash. The TDOM was considered to be the difference between the incubated and non-degraded OM amounts after 48 hours; meanwhile, the difference between the amount of incubated NDF and the non-degraded amounts was considered as truly degraded NDF (TDNDF). Ruminal ammonia concentrations were determined calorimetrically (Konitzer and Voigt, 1963) by a commercial enzymatic kit (Biodignstic inc, Alexandria, Egypt). Neubauer improved the bright-line counting chamber, and methyl green-formalin-saline solution was used to count protozoa microscopy as described by Konitzer and Voigt (1963). According to Soltan et al. (2018) and Salama et al. (2020) adaptation for Palmquist and Conrad (1971) method, the short-chain fatty acids (SCFAs) were determined by a gas chromatograph (Thermo TRACE 1300, Rodano, Milan, Italy) and equipped with a capillary column (TRFFAP $30 \mathrm{~m} \times 0.53 \mathrm{~mm}$ ID $\times$ $0.5 \mu \mathrm{m}$ film (Thermo-part No: 260N225P).

\section{Statistical analysis}

The in vitro assay was completed in one run with eight replication for each treatment. The experimental design was a complete randomized block design and data were analyzed for the feed ingredients parameters with one-way analysis of variance using the General Linear Model (PROC GLM) procedure of SAS (SAS Institute Inc. 2014. SASß OnDemand for Academics. Cary, NC) (SAS, 2015). Different diets parameters comparisons were analyzed with a factorial model using the PROC MIXED procedure of SAS, the model included the fixed effects of the forage type (alfalfa or Leucaena), with or without banana, and their interactions. The incubation bottle was the experimental unite. Comparisons of differences among treatments were considered significant at $p \leq 0.05$ using Duncan's Multiple Range test (Steel and Torrie, 1980).

\section{RESULTS}

\section{Chemical composition of feed ingredients and tested diets}

The chemical composition of the feed ingredients and diets used in the in vitro evaluation is provided in Table 1. Data indicated that values of OM content were similar for Leucaena and grass, whereas higher values of OM were observed with green banana and alfalfa. Leucaena presented higher CP and EE than alfalfa. The total phenols and total tannins of Leucaena were about 10 and 5 times higher than alfalfa, respectively. Meanwhile, alfalfa was higher than Leucaena in NDF and ADF. The green banana fruits had the lowest values of CP, EE, NDF, ADF, and ADL compared with other feed ingredients. The highest values of NDF and ADL content were recorded for grass hay. Leucaena plus grass hay and LGB diets showed higher values of CP, EE, total phenols, and total tannins than AG and AGB diets (Table 
Table 1. Chemical composition of experimental feed ingredients and diets

\begin{tabular}{lcccc|cccc}
\hline \multirow{2}{*}{ Chemical composition } & \multicolumn{3}{c}{ Feed ingredients } & \multicolumn{4}{c}{ Experimental diets } \\
\cline { 2 - 8 } & Alfalfa & Leucaena & $\begin{array}{c}\text { Green } \\
\text { banana }\end{array}$ & $\begin{array}{c}\text { Grass } \\
\text { hay }\end{array}$ & AG & AGB & LG & LGB \\
\hline Organic matter (g/kg DM) & 940 & 910 & 950 & 910 & 921 & 925 & 910 & 914 \\
Crude protein (g/kg DM) & 168 & 220 & 44 & 120 & 137 & 129 & 155 & 147 \\
Ether extract (g/kg DM) & 32.0 & 85.3 & 14.1 & 45.1 & 40.5 & 37.4 & 59.2 & 56.1 \\
Neutral detergent fiber (g/kg DM) & 368 & 221 & 71.6 & 600 & 519 & 466 & 467 & 415 \\
Acid Detergent fiber (g/kg DM) & 291 & 144 & 23.7 & 258 & 270 & 246 & 218 & 195 \\
Acid Detergent lignin (g/kg DM) & 69.8 & 60.2 & 18.5 & 99.0 & 88.8 & 80.7 & 85.4 & 77.4 \\
Total phenols* & 4.42 & 40.7 & 1.78 & 7.50 & 6.42 & 5.85 & 19.1 & 18.5 \\
Total tannins (\%) & 0.75 & 4.43 & 0.63 & 1.39 & 1.17 & 1.09 & 2.45 & 2.38 \\
\hline AG: afl
\end{tabular}

AG: alfalfa and grass hay at a ratio of 35:65, AGB: Alfalfa, grass hay, and green banana fruits at a ratio of 35:55:10, LG and AGB prepared by replacing alfalfa in AG and AGB with Leucaena leaves, respectively. *: Eq- to Gallic acid (g)/DM (kg).

Table 2. Phenolic components of the experimental feed ingredients detected by high-performance liquid chromatography

\begin{tabular}{|c|c|c|c|c|c|c|c|}
\hline \multirow[b]{2}{*}{ Phenolic components } & \multirow{2}{*}{$\begin{array}{l}\text { Retention } \\
\text { time (min) }\end{array}$} & \multirow{2}{*}{$\begin{array}{l}\text { Molecular } \\
\text { formula }\end{array}$} & \multirow{2}{*}{$\begin{array}{c}\text { Molecular } \\
\text { weight }(\mathrm{g} / \mathrm{mol})\end{array}$} & \multicolumn{4}{|c|}{ Concentration $(\mu \mathrm{g} / \mathrm{ml}$ ethanolic extraction) } \\
\hline & & & & Alfalfa & Leucaena & $\begin{array}{c}\text { Green } \\
\text { banana }\end{array}$ & Grass hay \\
\hline Gallic acid & 3.04 & $\mathrm{C}_{7} \mathrm{H}_{6} \mathrm{O}_{5}$ & 170.12 & 12.71 & 331.58 & 60.57 & 40.61 \\
\hline Chlorogenic acid & 3.80 & $\mathrm{C}_{16} \mathrm{H}_{18} \mathrm{O}_{9}$ & 354.31 & 41.2 & 99.76 & 9.31 & 27.74 \\
\hline Catechin & 4.123 & $\mathrm{C}_{15} \mathrm{H}_{14} \mathrm{O}_{6}$ & 290.26 & 2.2 & 131.5 & 1.47 & 16.85 \\
\hline Methyl gallate & 5.00 & $\mathrm{C}_{8} \mathrm{H}_{8} \mathrm{O}_{5}$ & 184.15 & 0.31 & 26 & 0.23 & 17.34 \\
\hline Caffeic acid & 5.39 & $\mathrm{C}_{9} \mathrm{H}_{8} \mathrm{O}_{4}$ & 180.16 & 0.91 & 31.49 & 10.38 & 60.36 \\
\hline Syringic acid & 5.88 & $\mathrm{C}_{9} \mathrm{H}_{10} \mathrm{O}_{5}$ & 198.17 & 0.79 & 21.18 & ND & 1.48 \\
\hline Pyro catechol & 6.05 & $\mathrm{C}_{6} \mathrm{H}_{6} \mathrm{O}_{2}$ & 110.1 & ND & 13.6 & ND & ND \\
\hline Rutin & 7.15 & $\mathrm{C}_{27} \mathrm{H}_{6} \mathrm{O}_{5}$ & 610.5 & 33.88 & 81.29 & ND & 22.91 \\
\hline Ellagic acid & 7.91 & $\mathrm{C}_{7} \mathrm{H}_{30} \mathrm{O}_{16}$ & 302.19 & 13.02 & 391.15 & 1.38 & 3.21 \\
\hline Coumaric acid & 8.15 & $\mathrm{C}_{9} \mathrm{H}_{8} \mathrm{O}_{3}$ & 164.16 & ND & 42.89 & ND & 10.28 \\
\hline Vanillin & 8.76 & $\mathrm{C}_{8} \mathrm{H}_{8} \mathrm{O}_{4}$ & 168.14 & ND & 36.54 & ND & 3.93 \\
\hline Ferulic acid & 9.48 & $\mathrm{C}_{10} \mathrm{H}_{10} \mathrm{O}_{4}$ & 194.18 & 2.01 & 2.69 & 0.85 & 17.18 \\
\hline Naringenin & 10.13 & $\mathrm{C}_{15} \mathrm{H}_{12} \mathrm{O}_{5}$ & 272.25 & 3.53 & 529.24 & 0.79 & 6.19 \\
\hline Querectin & 12.96 & $\mathrm{C}_{15} \mathrm{H}_{10} \mathrm{O}_{7}$ & 302.2 & 3.55 & 6.15 & 1.01 & 2.17 \\
\hline Cinnamic acid & 14.19 & $\mathrm{C}_{9} \mathrm{H}_{8} \mathrm{O}_{2}$ & 148.15 & 0.27 & 1.87 & 0.17 & 0.89 \\
\hline Kaempferol & 15.35 & $\mathrm{C}_{15} \mathrm{H}_{10} \mathrm{O}_{6}$ & 286.2 & 6.01 & 5.69 & ND & 8.75 \\
\hline Hesperetin & 15.88 & $\mathrm{C}_{16} \mathrm{H}_{14} \mathrm{O}_{6}$ & 302.27 & ND & ND & ND & 0.65 \\
\hline
\end{tabular}

\section{Phenolic components by HPLC analysis}

Table 2 presents the concentration of 17 phenolic components determined in the extract of the experimental feed ingredients. Leucaena has the highest concentration of 13 out of 17 tested phenolic components. Gallic acid, ellagic acid, and naringenin were the most phenolic components detected in Leucaena extract. Pyro catechol was found only in Leucaena extract, while coumaric acid and vanillin have been found in the extract of Leucaena and grass hay and undetected in alfalfa and green banana extracts. Leucaena indicated a high content of different components with antioxidant and anti-inflammatory properties, such as catechin, gallic acid, chlorogenic acid, ellagic acid, and naringenin (Table 2).

\section{In vitro gas production of feed ingredients and tested diets}

Table 3 presents the gas production $(\mathrm{ml} / \mathrm{g} \mathrm{DM})$ after 4, 8, 12, 24, 48 hours and total accumulative after 24 hours of the feed ingredients and tested diets incubation. Results declared that there was a significant difference among the tested ingredients throughout all the measured times of incubation ( $p<0.05)$. The gas production (GP) at 4 hours after incubation was significantly higher for alfalfa, compared with other feed ingredients. While at 8 and 12 hours after 
incubation, alfalfa and banana fruits were significantly higher in gas production than other ingredients. On the other hand, at 24, 48, and total accumulative 24 hours, the GP of banana fruits was significantly the highest as 61.5, 67.5, and $192.9 \mathrm{ml} / \mathrm{g} \mathrm{DM}$, respectively, compared with other ingredients $(\mathrm{p}<0.05)$. Contrarily, Leucaena significantly indicated the lowest values for gas production at 12, 24, 48 hours as well as the total accumulative at 24 hours of incubation ( $p<$ 0.05). Concerning the forage effect, the GP at all the measure times of incubation (except 4 hours) for the alfalfa diet was significantly higher than the Leucaena diet, which directly reflected on the total accumulative gas value for 24 hours of incubation being $122 \mathrm{ml} / \mathrm{g}$ DM for alfalfa vs. $111 \mathrm{ml} / \mathrm{g}$ DM for Leucaena. It was observed that the presence of banana in the diet as an energy source significantly increased the gas production at 4, 12, 24 and the accumulative at 24 hours, and decreased the GP value at 48 hours compared with the diets without banana. The interaction between forage and energy was not significant at any measured time periods.

Table 3. In vitro gas production characteristics for feed ingredients and diets

\begin{tabular}{|c|c|c|c|c|c|c|}
\hline \multirow[b]{2}{*}{ Ingredients/diets } & \multicolumn{6}{|c|}{ Gas production (ml/g DM) } \\
\hline & 4 hours & 8 hours & 12 hours & 24 hours & 48 hours & $\begin{array}{r}\text { Accumulati } \\
24 \text { hours } \\
\end{array}$ \\
\hline & \multicolumn{6}{|c|}{ Feed ingredients } \\
\hline Alfalfa & $45.8^{\mathrm{a}}$ & $19.9^{\mathrm{a}}$ & $29.1^{\mathrm{a}}$ & $39.6^{\mathrm{b}}$ & $26.5^{\mathrm{c}}$ & $133.8^{\mathrm{b}}$ \\
\hline Leucaena & $38.2^{\mathrm{b}}$ & $12.9^{\mathrm{b}}$ & $15.1^{\mathrm{c}}$ & $27.1^{\mathrm{c}}$ & $24.5^{\mathrm{c}}$ & $90.7^{\mathrm{c}}$ \\
\hline Banana & $38.9^{\mathrm{b}}$ & $18.2^{\mathrm{a}}$ & $33.9^{\mathrm{a}}$ & $61.5^{\mathrm{a}}$ & $67.5^{\mathrm{a}}$ & $192.9^{\mathrm{a}}$ \\
\hline Grass Hay & $37.0^{\mathrm{b}}$ & $14.6^{\mathrm{b}}$ & $22.9^{\mathrm{b}}$ & $39.4^{\mathrm{b}}$ & $43.2^{\mathrm{b}}$ & $130.1^{\mathrm{b}}$ \\
\hline SEM & 2.60 & 2.94 & 4.75 & 4.86 & 4.23 & 11.76 \\
\hline \multirow[t]{2}{*}{$\mathrm{p}$ value } & $<0.0001$ & $<0.0001$ & $<0.0001$ & $<0.0001$ & $<0.0001$ & $<0.0001$ \\
\hline & \multicolumn{6}{|c|}{ Alfalfa diets vs. Leucaena diets } \\
\hline \multicolumn{7}{|l|}{ Forage effect } \\
\hline Alfalfa & 35.6 & $18.1^{\mathrm{a}}$ & $24.3^{\mathrm{a}}$ & $36.5^{\mathrm{a}}$ & $34.6^{\mathrm{b}}$ & $122^{\mathrm{a}}$ \\
\hline Leucaena & 33.6 & $13.5^{\mathrm{b}}$ & $20.2^{\mathrm{b}}$ & $32.1^{\mathrm{b}}$ & $38.9^{\mathrm{a}}$ & $111^{\mathrm{b}}$ \\
\hline $\mathrm{p}$ value & 0.1599 & 0.0056 & $<0.0001$ & $<0.0001$ & $<0.0001$ & 0.0043 \\
\hline \multicolumn{7}{|l|}{ Energy effect } \\
\hline No banana & $32.7^{\mathrm{b}}$ & 15.8 & $19.9^{\mathrm{b}}$ & $32.6^{\mathrm{b}}$ & $37.9^{\mathrm{a}}$ & $112^{\mathrm{b}}$ \\
\hline Banana & $36.5^{\mathrm{a}}$ & 15.8 & $24.7^{\mathrm{a}}$ & $36.0^{\mathrm{a}}$ & $35.6^{\mathrm{b}}$ & $122^{\mathrm{a}}$ \\
\hline $\mathrm{p}$ value & 0.0093 & 0.9835 & $<0.0001$ & 0.0008 & 0.006 & 0.0085 \\
\hline \multicolumn{7}{|l|}{ Forage $\times$ Energy } \\
\hline AG & 33.9 & 18.9 & 22.4 & 35.7 & 35.4 & 119.1 \\
\hline AGB & 37.3 & 17.3 & 26.3 & 37.2 & 33.8 & 124.8 \\
\hline LG & 31.6 & 12.7 & 17.4 & 29.5 & 40.4 & 104.5 \\
\hline LGB & 35.7 & 14.2 & 23.1 & 34.7 & 37.4 & 118.2 \\
\hline $\mathrm{p}$ value & 0.7783 & 0.3237 & 0.1496 & 0.0514 & 0.3714 & 0.252 \\
\hline SEM & 3.76 & 4.23 & 1.72 & 2.53 & 2.15 & 9.47 \\
\hline
\end{tabular}

SEM: Standard error of the mean, AG: alfalfa and grass hay at a ratio of 35:65, AGB: Alfalfa, grass hay, and green banana fruits at a ratio of 35:55:10, LG and AGB prepared by replacing alfalfa in AG and AGB with Leucaena leaves, respectively. Values for different comparisons in the same column with different superscripts letters are significantly different $(\mathrm{p}<0.05)$.

\section{Ruminal pH, ammonia concentration, nutrient degradability, and protozoal count}

The values of $\mathrm{pH}$ after 48 hours of incubation differ significantly among feed ingredients $(\mathrm{p}<0.05)$. The highest value was observed for Leucaena as 6.23, whereas the lowest value recorded for banana fruits was 5.24 (Table 4). The $\mathrm{NH}_{3}-\mathrm{N}$ concentration for alfalfa and grass hay was similar but significantly higher than Leucaena $(\mathrm{p}<0.05)$, meanwhile banana showed the lowest value of $9.0 \mathrm{mg} / 100 \mathrm{ml}$. Comparing $\mathrm{pH}$ values or $\mathrm{NH}_{3}-\mathrm{N}$ concentration of different diets neither forage, energy nor interaction between them were significantly different.

Results of degraded organic matter (DOM) indicated that banana fruits had the highest value being $905.3 \mathrm{~g} / \mathrm{kg}$, while Leucaena had the lowest value being $588.0 \mathrm{~g} / \mathrm{kg}$. Besides, the alfalfa diet had a significantly higher value for DOM in comparison with the Leucaena diet being $691.3 \mathrm{vs.} 657.5 \mathrm{~g} / \mathrm{kg}$, respectively. In the same trend, the presence of banana fruits significantly $(\mathrm{p}<0.05)$ enhances the DOM. However, there was an interaction between forage type and the presence of banana, making Leucaena diet significantly lower in DOM either with banana $660.5 \mathrm{~g} / \mathrm{kg}$ or without 654.5 $\mathrm{g} / \mathrm{kg}$. In contrast to DOM results, Leucaena significantly recorded $(\mathrm{p}<0.05)$ the highest value for DNDF, compared to other tested feed ingredients, while banana fruits had the lowest value. Also, diets with bananas showed a significantly lowest TDOM, compared to other diets $(\mathrm{p}<0.05)$. No significant difference was observed for the protozoal count values $\left(10^{5} / \mathrm{ml}\right)$ among different feed ingredients and tested diets (Table 4$)$.

To cite this paper: Salama Rashid MR, Hanafy MA, Youssef MSH, Archimède H, Sallam SMA, Soltan YA, and Ali Ghoneem WM (2021). Chemical and in vitro evaluation of Leucaena (Leucaena leucocephala) Leaves as a Substitute of Alfalfa (Medicago sativa L.) with/without Rejected Green Banana Fruits (Musa paradisiaca). World Vet. J. 11 (4): 678-697. DOI: https://dx.doi.org/10.54203/scil.2021.wvj86 
Table 4. In vitro ruminal $\mathrm{pH}$, ammonia $\left(\mathrm{NH}_{3} \mathrm{~N}\right)$ concentrations, truly degraded organic matter (TDOM), truly degraded neutral detergent fiber (TDNDF), and protozoal count for feed ingredients and diets

\begin{tabular}{|c|c|c|c|c|c|}
\hline \multirow{2}{*}{ Ingredients/diets } & \multirow{2}{*}{ pH } & \multirow{2}{*}{$\begin{array}{c}\text { NH3-N } \\
(\mathrm{mg} / 100 \mathrm{ml})\end{array}$} & \multicolumn{2}{|c|}{ Degradability (g/kg) } & \multirow{2}{*}{$\begin{array}{l}\text { Protozoal count } \\
\left(10^{5} / \mathrm{ml}\right)\end{array}$} \\
\hline & & & TDOM & TDNDF & \\
\hline & \multicolumn{5}{|c|}{ Feed ingredients } \\
\hline Alfalfa & $5.94^{\mathrm{c}}$ & $39.2^{\mathrm{a}}$ & $767.0^{\mathrm{b}}$ & $408.7^{\mathrm{b}}$ & 6.30 \\
\hline Leucaena & $6.23^{\mathrm{a}}$ & $25.3^{\mathrm{b}}$ & $588.0^{\mathrm{d}}$ & $690.0^{\mathrm{a}}$ & 7.35 \\
\hline Banana & $5.24^{\mathrm{d}}$ & $9.00^{c}$ & $905.3^{\mathrm{a}}$ & $187.1^{\mathrm{c}}$ & 6.83 \\
\hline Grass Hay & $6.03^{\mathrm{b}}$ & $37.9^{\mathrm{a}}$ & $659.2^{\mathrm{c}}$ & $485.5^{\mathrm{b}}$ & 6.15 \\
\hline SEM & 0.04 & 3.18 & 15.6 & 64.20 & 1.41 \\
\hline \multirow[t]{2}{*}{$\mathrm{p}$ value } & $<0.0001$ & $<0.0001$ & $<0.0001$ & $<0.0001$ & 0.6890 \\
\hline & \multicolumn{5}{|c|}{ Alfalfa diets vs. Leucaena diets } \\
\hline \multicolumn{6}{|l|}{ Forage effect } \\
\hline Alfalfa & 5.88 & 31.0 & $691.3^{\mathrm{a}}$ & $424.1^{\mathrm{a}}$ & 7.31 \\
\hline Leucaena & 6.05 & 37.6 & $657.5^{\mathrm{b}}$ & $291.9^{\mathrm{b}}$ & 6.79 \\
\hline $\mathrm{p}$ value & 0.1026 & 0.0711 & $<0.0001$ & $<0.0001$ & 0.5174 \\
\hline \multicolumn{6}{|l|}{ Energy effect } \\
\hline No banana & 6.03 & 37.5 & $669.5^{\mathrm{b}}$ & $386.9^{\mathrm{a}}$ & 6.98 \\
\hline Banana & 5.91 & 31.0 & $679.3^{\mathrm{a}}$ & $329.1^{\mathrm{b}}$ & 7.13 \\
\hline $\mathrm{p}$ value & 0.2096 & 0.0733 & 0.0276 & $<0.0001$ & 0.8521 \\
\hline \multicolumn{6}{|l|}{ Forage $\times$ Energy } \\
\hline $\mathrm{AG}$ & 5.90 & 35.7 & $678.4^{\mathrm{b}}$ & $432.4^{\mathrm{a}}$ & 7.88 \\
\hline AGB & 5.87 & 26.3 & $704.1^{\mathrm{a}}$ & $419.9^{\mathrm{a}}$ & 6.75 \\
\hline LG & 6.16 & 39.4 & $660.5^{\mathrm{c}}$ & $341.5^{\mathrm{b}}$ & 6.08 \\
\hline LGB & 5.94 & 35.7 & $654.5^{\mathrm{c}}$ & $242.4^{c}$ & 7.50 \\
\hline $\mathrm{p}$ value & 0.3498 & 0.4094 & 0.0016 & 0.0002 & 0.1313 \\
\hline SEM & 0.19 & 6.34 & 7.81 & 15.34 & 1.57 \\
\hline
\end{tabular}

SEM: Standard error of the mean, TDOM: Truly degraded organic matter, TDNDF: Truly degraded neutral detergent fiber, AG: alfalfa and grass hay at a ratio of 35:65, AGB: Alfalfa, grass hay, and green banana fruits at a ratio of 35:55:10, LG and AGB prepared by replacing alfalfa in AG and AGB with Leucaena leaves, respectively. Values for different comparisons in the same column with different superscripts letters are significantly different (p $<0.05)$.

Table 5. Molar proportions of individual short-chain fatty acids (SCFAs), total SCFAs concentration, and acetate to propionate ratio $\left(\mathrm{C}_{2} / \mathrm{C}_{3}\right)$ for feed ingredients and diets

\begin{tabular}{|c|c|c|c|c|c|c|c|c|}
\hline \multirow[b]{2}{*}{ Ingredients/diets } & \multicolumn{6}{|c|}{ Molar proportions of individual SCFAs (\% of total SCFAs) } & \multirow{2}{*}{$\begin{array}{c}\text { Total } \\
\text { SCFAs mM }\end{array}$} & \multirow{2}{*}{$\begin{array}{l}\mathrm{C}_{2} / \mathrm{C}_{3} \\
\text { ratio }\end{array}$} \\
\hline & Acetate & Propionate & Isobutyrate & Butyrate & Isovalerate & Valerate & & \\
\hline & \multicolumn{8}{|c|}{ Feed ingredients } \\
\hline Alfalfa & $64.5^{\mathrm{c}}$ & $16.2^{\mathrm{c}}$ & $2.85^{\mathrm{a}}$ & $10.2^{\mathrm{b}}$ & $3.59^{\mathrm{a}}$ & $2.57^{\mathrm{a}}$ & $99.1^{\mathrm{a}}$ & $3.99^{\mathrm{c}}$ \\
\hline Leucaena & $69.6^{\mathrm{a}}$ & $16.8^{\mathrm{b}}$ & $2.22^{\mathrm{b}}$ & $9.74^{\mathrm{c}}$ & $0.37^{\mathrm{d}}$ & $1.27^{\mathrm{c}}$ & $72.6^{\mathrm{c}}$ & $4.15^{\mathrm{b}}$ \\
\hline Banana & $56.2^{\mathrm{d}}$ & $17.8^{\mathrm{a}}$ & $1.52^{\mathrm{c}}$ & $23.2^{\mathrm{a}}$ & $0.86^{\mathrm{c}}$ & $1.42^{\mathrm{b}}$ & $93.5^{\mathrm{b}}$ & $3.15^{\mathrm{d}}$ \\
\hline Grass Hay & $67.6^{\mathrm{b}}$ & $15.5^{\mathrm{d}}$ & $2.80^{\mathrm{a}}$ & $10.5^{\mathrm{b}}$ & $2.06^{\mathrm{b}}$ & $1.47^{\mathrm{b}}$ & $74.1^{\mathrm{c}}$ & $4.36^{\mathrm{a}}$ \\
\hline SEM & 0.32 & 0.21 & 0.07 & 0.19 & 0.18 & 0.05 & 2.32 & 0.06 \\
\hline \multirow[t]{2}{*}{$\mathrm{p}$ value } & $<0.0001$ & $<0.0001$ & $<0.0001$ & $<0.0001$ & $<0.0001$ & $<0.0001$ & $<0.0001$ & $<0.0001$ \\
\hline & \multicolumn{8}{|c|}{ Alfalfa diets vs. Leucaena diets } \\
\hline \multicolumn{9}{|l|}{ Forage effect } \\
\hline Alfalfa & 65.8 & 15.7 & 2.59 & $11.2^{\mathrm{a}}$ & $2.79^{\mathrm{a}}$ & $1.83^{\mathrm{a}}$ & $92.7^{\mathrm{a}}$ & 4.18 \\
\hline Leucaena & 66.4 & 15.8 & 2.93 & $11.0^{\mathrm{b}}$ & $2.38^{\mathrm{b}}$ & $1.45^{\mathrm{b}}$ & $77.1^{\mathrm{b}}$ & 4.20 \\
\hline $\mathrm{p}$ value & 0.1952 & 0.5212 & 0.1791 & 0.0025 & 0.0148 & $<0.0001$ & 0.0132 & 0.7505 \\
\hline \multicolumn{9}{|l|}{ Energy effect } \\
\hline No banana & 66.2 & 15.8 & 3.00 & $10.5^{\mathrm{b}}$ & $2.80^{\mathrm{a}}$ & $1.70^{\mathrm{a}}$ & 82.9 & 4.18 \\
\hline Banana & 66.1 & 15.7 & 2.52 & $11.7^{\mathrm{a}}$ & $2.37^{\mathrm{b}}$ & $1.58^{\mathrm{b}}$ & 86.9 & 4.20 \\
\hline $\mathrm{p}$ value & 0.7398 & 0.5212 & 0.0761 & $<0.0001$ & 0.0105 & 0.0452 & 0.4407 & 0.7505 \\
\hline \multicolumn{9}{|l|}{ Forage $\times$ Energy } \\
\hline AG & 66.3 & 15.7 & 2.77 & 10.6 & $2.80^{\mathrm{a}}$ & 1.86 & 90.0 & 4.22 \\
\hline AGB & 65.4 & 15.8 & 2.40 & 11.9 & $2.77^{\mathrm{a}}$ & 1.79 & 95.4 & 4.14 \\
\hline LG & 66.1 & 16.0 & 3.23 & 10.3 & $2.80^{\mathrm{a}}$ & 1.53 & 75.8 & 4.26 \\
\hline LGB & 66.7 & 15.7 & 2.64 & 11.6 & $1.96^{\mathrm{b}}$ & 1.38 & 78.4 & 4.14 \\
\hline $\mathrm{p}$ value & 0.1239 & 0.296 & 0.6495 & 0.7802 & 0.0148 & 0.4023 & 0.7837 & 0.1155 \\
\hline SEM & 0.76 & 0.26 & 0.41 & 0.10 & 0.23 & 0.08 & 8.54 & 0.10 \\
\hline
\end{tabular}

$\mathrm{C}_{2} / \mathrm{C}_{3}=$ Acetate to propionate ratio, SEM: Standard error of the mean, SCFAs: Short-chain fatty acids, AG: alfalfa and grass hay at a ratio of 35:65, AGB: Alfalfa, grass hay, and green banana fruits at a ratio of 35:55:10, LG and AGB prepared by replacing alfalfa in AG and AGB with Leucaena leaves, respectively. Values for different comparisons in the same column with different superscripts letters are significantly different $(p<0.05)$.

To cite this paper: Salama Rashid MR, Hanafy MA, Youssef MSH, Archimède H, Sallam SMA, Soltan YA, and Ali Ghoneem WM (2021). Chemical and in vitro evaluation of Leucaena (Leucaena leucocephala) Leaves as a Substitute of Alfalfa (Medicago sativa L.) with/without Rejected Green Banana Fruits (Musa paradisiaca). World Vet. J. 11 (4): 678-697. DOI: https://dx.doi.org/10.54203/scil.2021.wvj86 


\section{Molar proportions of individual short-chain fatty acids (SCFAs), total SCFAs concentration, and C2/C3 ratio for feed ingredients and diets}

According to Table 5, Leucaena recorded the highest value for acetate, being $69.6 \%$ of total SCFAs. In contrast, banana fruits were the lowest for acetate $(56.2 \%)$ and isobutyrate $(1.52 \%)$, while banana resulted in the highest values for propionate and butyrate as $17.8 \%$ and $23.2 \%$ of total SCFAs, respectively, compared to other tested feed ingredients. The highest value of isobutyrate was observed for alfalfa and grass hay (2.85\% and $2.80 \%$ of total SCFAs, respectively). Leucaena incubation produced the lowest values of butyrate, isovalerate, valerate, and consequently total SCFAs, compared to the tested feed ingredients, while alfalfa recorded the highest values for isovalerate, valerate, and total SCFAs. The $\mathrm{C}_{2} / \mathrm{C}_{3}$ ratio (acetate to propionate ratio) for grass hay incubation was the highest value (4.36) while banana recorded the lowest ratio of 3.15. Regarding the effect of diet, all experimental diets had the same proportions of acetate, propionate, and isobutyrate as a percentage of total SCFAs, with no significant effect for neither forage nor energy and interaction. The forage type effect on producing butyrate, isovalerate, valerate was significantly higher in alfalfa diet, compared to the Leucaena diet, and consequently, total SCFAs recorded the highest value for the alfalfa diet. Regardless of the roughage type, the presence of banana in the diet significantly decreased the isovalerate and valerate percentage of total SCFAs, while increasing the butyrate percentage of total SCFAs $(\mathrm{p}<0.05$; Table 5).

\section{DISCUSSION}

\section{Chemical composition of the feed ingredients and tested diets}

This study aimed to characterize the chemical composition, phenolic compounds profile, and in vitro evaluation of non-conventional feed (Leucaena leaves) and compared it with traditional feed (alfalfa), besides assessing the possibility to use rejected green banana fruits as a source of energy. In the current study, the OM, CP, NDF, and ADF values for Leucaena and grass hay (except CP) were found to be lower than the recorded values by Rira et al. (2015) and Archimède et al. (2016) for the same ingredients. Moreover, the values of CP and fiber fraction of banana fruits were lower than banana chemical composition noted by Archimède et al. (2010).

The chemical composition of feed ingredients showed that Leucaena had higher CP, EE, TP, and TT than alfalfa which reflected in the chemical composition of LG and LGB diets, compared to AG and AGB diets. Similarly, it has been reported that Leucaena leaf meal had higher levels of CP, EE, and total tannins than alfalfa hay (Mohammadabadi and Jolazadeh, 2017).

In this context, results evidenced that the inclusion of Leucaena leaves in the diet may increase the contents of $\mathrm{CP}$, EE, total phenols, and total tannins in comparison with the control diet (Montoya-Flores et al., 2020). The previous results are in harmony with a study by Soltan et al. (2017) indicating the potential use of Leucaena as a traditional legume forage in rations of ruminant livestock in tropical and subtropical areas, compared to alfalfa and Tifton hays due to its low fiber and high CP contents.

The current results revealed that the highest OM content and the lowest values of other chemical compositions of green banana were reflected on the chemical composition of diets containing banana fruits (AGB and LGB), compared to the same diets without banana fruits (AG and LG).

\section{Feed ingredients phenolic components}

Generally, phenolic components displayed a wide range of biological activities. The obtained results of the current study revealed that Leucaena had the highest concentration of total phenols (40.7 eq- to Gallic acid (g)/DM (kg)); consequently, the concentration of the majority of determined phenolic components was the highest for the Leucaena ethanolic extract. Several beneficial effects for humans, animals, and poultry are reported for naringenin (class: flavanones), ellagic acid, gallic acid, and catechin (class: flavanols), including antioxidant, anti-inflammatory, and pharmacological properties (Shakeel et al., 2017; Changxing et al., 2018; Bae et al., 2020; Yang et al., 2020). Ellagic acid and gallic acid (ellagitannins and gallotannins) are responsible for the formation of Leucaena tannins content by esterified partially/wholly tannins central core (polyhydric alcohol; Serra et al., 2021). The main phenolic components in Leucaena extract in the current study were detected by HPLC using 17 standards. On the other hand, chlorogenic acid is found to be the major phenolic component in alfalfa extract (13 components detected out of 17); this compound has been found to have hypoglycemic, hypolipidemic, anti-inflammatory, antioxidant, and other pharmacological properties (Yan et al., 2020). Results also clarified that chlorogenic acid concentration in Leucaena extract was higher than the double concentration for alfalfa ( $99.76 \mathrm{vs.} 41.2 \mu \mathrm{g} / \mathrm{ml}$, respectively).

Banana fruits are known to be rich not only in carbohydrates, specific vitamins, or minerals but are also rich in many health-promoting bioactive phytochemicals. The obtained results of HPLC indicated that 10 phenolic compounds were detected in green fruit extract. Out of these components, gallic acid was the principal phenolic acid which had the highest value $(60.57 \mu \mathrm{g} / \mathrm{ml}$ extract). Gallic acid was reported to have health benefits like antioxidant and potential hepatoprotective effects (Sidhu and Zafar, 2018). Concerning tropical grass hay, caffeic acid recorded the highest value 
$(60.36 \mu \mathrm{g} / \mathrm{ml}$ extract), compared to other feed ingredients. Caffeic acid belongs to the non-flavonoid-polyphenols group, a class of micronutrients known for their antioxidant properties (Serra et al., 2021).

\section{Nutritional evaluation of feed ingredients and tested diets}

The gas production technique has been used in many studies as a significant tool for feed evaluation due to its high analytical capacity, low cost, and avoid animal capitation. The in vitro incubation of feeds with buffered rumen fluid let the carbohydrates (structural and nonstructural) ferment and produce SCFAs, gases, and microbial cells. The production of gases is the consequence of carbohydrates fermentation (GP from protein and fat fermentation is relatively small vs. carbohydrates) to acetate and butyrate, meanwhile, lower gas production is associated with propionate production (gas only from buffering of the acid) (Makkar, 2002). Therefore, the difference in the GP values among our experimental feed ingredients throughout all the measure times $(4,8,12,24$, and 48 hours post-incubation) suggested that the fermentation of the available nutrients also differs.

Alfalfa showed a significantly high GP value, compared to Leucaena; meanwhile, green banana fruits were similar to alfalfa at 8, 12 hours of incubation and recorded the highest significant values for GP at 24, 48 hours and the accumulative 24 hours of incubation. The results concerning the green banana could be related to an increase in fermentable carbohydrates in green fruits, as indicated by the lowest $\mathrm{pH}$ value recorded for green banana fruits (Table 4), which may provide a more accessible substrate for ruminal microorganisms (Schulmeister et al., 2020). While in the alfalfa case, it could be correlated with high fermentable nitrogen from microbial activity (Taghizadeh et al., 2008) resulting in high microbial growth rates. In the current study, the values for alfalfa GP were lower but in the same increasing trend with Taghizadeh et al. (2008). In the present work, Leucaena showed the lowest values for GP at different incubation times. In many in vitro and in vivo studies the inclusion of animal diet with Leucaena or Leucaena tannins extract has been tested (Tan et al., 2011; Harrison et al., 2015; Piñeiro-Vázquez et al., 2018). The total 24 hours accumulative GP for Leucaena was 32\% lower than alfalfa. In this context, Rira et al. (2015) included 100\% of Leucaena in an in vitro system resulted in the reductions of $18 \%$ in total 24 hours GP and $31.5 \%$ in $\mathrm{CH}_{4}$ production. The total replacement of alfalfa with Leucaena (35\% of diet DM) significantly affects GP with a $9 \%$ decrease in accumulative 24 hours.

In the same trend, a negative relationship between GP and inclusion of some tanniferous plants was detected by Gomaa et al. (2017), Aderao et al. (2018), and Jayanegara et al. (2018). That reduction in GP may be due to the antimicrobial property of tannins and other phenolic compounds in these plants (Francis et al., 2002) or could be attributed to the reduction in microbial enzymatic degradation and microbial growth as a result of the ability of CT to bind with fiber and protein (Tavendale et al., 2005; Bhatta et al., 2012; Pal et al., 2015). Moreover, Chaji et al. (2020) explained the reduction in GP by the disruption effect of tannins on rumen microorganisms.

Although GP decreased with Leucaena at all incubation periods, the GP at 48 hours of incubation increased with diets containing Leucaena (LG and LGB). The previous result may be associated with the adaptability of rumen microbes and their ability to degrade some of the secondary metabolites (Hart et al., 2008). The presence of mimosine in Leucaena could be used as an energy source (Soltan et al., 2017), or may be related to lower contents of NDF with these rations, compared to non-Leucaena diets of AG and AGB (Table 1), which provide more soluble carbohydrates that lead to increase fermentation activity (Noviandi et al., 2021). In the same trend, Getachew et al. (2008a) recorded increases in rumen degradability at 48 hours, compared with earlier incubation periods with tannic acid supplementation to alfalfa hay, and explained that by ruminal microbe's adaptation to tannins. Moreover, the presence of tannin metabolites, such as ellagic acid and gallic acid in the rumen (Murdiati et al., 1992) may confirm the degradation of tannin by rumen microorganisms.

\section{Ruminal fermentation, nutrient degradability, and protozoal count}

The results of Erfle et al. (1982) studies showed that low pH (less than 6) resulted in low ammonia concentration in a continuous in vitro fermentation system. Results herein showed that the final $\mathrm{pH}$ and $\mathrm{NH}_{3}-\mathrm{N}$ concentration were significantly lower with banana fruits, compared to other feed ingredients. The low nitrogen content in green bananas could be the main reason for the low $\mathrm{NH}_{3}-\mathrm{N}$ concentration, which could affect the growth of certain bacteria that require ammonia (Erfle et al., 1982). Moreover, it is well known that the rapid degradation of alfalfa protein by ruminants can reduce nitrogen utilization (Getachew et al., 2008a; Getachew et al., 2008b), which lead to an increase in the cost of protein supplementation and increase nitrogen excretion contributing to environmental pollution (Getachew et al., 2008b). Therefore, the inclusion of rich tannin forages in the ruminant ration, Leucaena in the current study, could increase nitrogen utilization as a result of binding tannins with protein which decrease rumen protein degradability (Getachew et al., 2000) and increase its absorption from the lower gut (Waghorn et al., 1987).

Leucaena recorded the highest values of $\mathrm{pH}$, followed by grass hay (6.23 vs. 6.03), while $\mathrm{NH}_{3}-\mathrm{N}$ concentrations were 25.3 and $37.9 \mathrm{mg} / 100 \mathrm{ml}$, respectively. Moreover, the results of the present study indicated a significant decrease in $\mathrm{NH}_{3}-\mathrm{N}$ concentration with Leucaena as a feed ingredient, compared to alfalfa. In the same context, a reduction in $\mathrm{NH}_{3}-\mathrm{N}$ 
concentration with Leucaena was reported by Soltan et al. (2012). Furthermore, Bhatta et al. (2005, 2007) confirmed lower $\mathrm{NH}_{3}-\mathrm{N}$, either with goats or sheep fed on tannin containing plants (Prosopis cineraria). This reduction in ruminal $\mathrm{NH}_{3}-\mathrm{N}$ concentration may be due to $\mathrm{CT}$ content in Leucaena which inhibits the deamination process (Szumacher-Strabel and Cieślak, 2010; Goel and Makkar, 2012) and protein degradation in the rumen by forming hardly degraded complexes with protein (McSweeney et al., 1999). Moreoever, Jouany (1994) explained that reduction by the inhibition effect of CT on the bacteria-degrading activity of protozoa. In contrast, the results of the present study indicated non-significant increases in the concentration of $\mathrm{NH}_{3}-\mathrm{N}$ with Leucaena rations (LG and LGB). Moreover, the result obtained by Harun et al. (2017) were in agreement with the previous result, which may be explained by higher CP content in these rations.

Regarding the results of the truly degraded organic matter (TDOM), banana fruits had the highest value, and Leucaena had the lowest value (905.3 vs. $588.0 \mathrm{~g} / \mathrm{kg}$ OM, respectively). Results for TDOM of Leucaena were similar to that found by Soltan et al. (2012) as $588 \mathrm{~g} / \mathrm{kg}$ OM, compared to $504 \mathrm{~g} / \mathrm{kg}$ OM for Tifton hay. The ability of tannin hydroxyl groups to form complexes with protein, amino acids, metal ions, and polysaccharides can be the reason for the reduction in rumen degradability of OM (Sallam et al., 2010; Jayanegara et al., 2018). Also, Ultee et al. (2002) confirmed the high antimicrobial effect of the plant secondary metabolites that contain hydroxyl group in its phenolic structure, which reduced feed digestibility (Hariadi and Santoso, 2010). Another explanation of the low TDOM results for Leucaena was also reported by Rira et al. (2015) as a consequence of volatile fatty acids decrease; likewise, total SCFAs result of the current study was low in Leucaena (Table 5). Besides, Tan et al. (2011) found a linear decrease of in vitro digestibility with increasing CT content.

As tropical grasses typically require supplementation of protein and energy to satisfy ruminal microbial growth, improve feed intake, and promote fiber digestion, the supplementation of banana fruit substrate, as a concentrate, may also improve animal performance. The green banana fruits had the highest value for TDOM (905.3 g/ $/ \mathrm{kg} \mathrm{OM})$, which is identical to results for ripe banana fruits $(904.4 \mathrm{~g} / \mathrm{kg} \mathrm{OM})$ and lower than green fruits $(802.9 \mathrm{~g} / \mathrm{kg}$ OM) in the present study (Schulmeister et al., 2020). On the other hand, TDNDF value for banana fruits was significantly the lowest in the current study, which suggests that incubation of substrate with low content in both NDF and protein, formed a high resistance NDF-protein complex against degradation (Pieltain et al., 1998). Concerning diets, Leucaena decreased the TDNDF, compared with alfalfa (291.9 vs. $424.1 \mathrm{~g} / \mathrm{kg} \mathrm{DM})$. These results confirmed the findings indicated by Mohammadabadi and Jolazadeh (2017) who found that the in vivo NDF disappearance decreased when $50 \%$ of alfalfa was replaced by Leucaena leaves in Najdi goats' diet.

Many theories have been established to explain that reduction in degraded NDF with tannin-rich plants may be due to the effect of tannin on reducing the number or activity of rumen cellulolytic bacteria (Singleton, 1981; Makkar, 1993), such as Butyrivibrio fibrosolvens (Jones et al., 1994), or inhibiting ruminal degradation by binding with cellulose and forming complexes (McSweeney et al., 2001). Bueno et al. (2008) and Rodríguez et al. (2015) confirmed the tannins effects on rumen bacteria activity. However, decreases in TDNDF were observed in the present study with Leucaena diets, TDNDF was significantly increased when Leucaena was incubated alone. The obtained results of the current study suggest the adaptation of rumen microbes to Leucaena tannin especially when there is no other feed ingredient. McSweeney et al. (2001) and Patra and Saxena (2009) reported that some ruminal microbes can be adapted to CT by producing polymers for tannin degradation enzymes and cellular protection.

Phenolic structures may disrupt protozoal membranes, inactivate protozoal enzymes, and deprive protozoa of substrates and metal ions which are essential for cell metabolism (Patra and Saxena, 2011). In the current study there was no significant difference in protozoal count among ingredients or different diets, which was in harmony with results obtained by Angarita et al. (2015) and Montoya-Flores et al. (2020) indicating no effects of Leucaena on rumen microbes count (bacteria and protozoa) quantified by qPCR. Moreover, Wallace et al. (2015) and Saminathan et al. (2016) cleared that reducing digestibility with CT diets without affecting rumen microorganisms may be attributed to the inhibition effect of CT on enzymatic activity or ruminal bacteria. The diversity response of rumen degradability to the inclusion of tannin rich plants may be related to the differences in molecular weight and chemical structure of CT which are affected by many factors, such as species, Genotype, and growth stage of these plants (Huang et al., 2010; Theodoridou et al., 2010).

Rumen fermentation of slowly fermentable carbohydrates produced higher acetate, compared to propionate. Banana is classified as a starch source with a slow rate of degradation (Makkar, 2002). In this context, the current study demonstrated more propionate and lower acetate to propionate ratio for bananas. The decreases in total SCFAs with Leucaena feed ingredients or diets are in agreement with Makkar et al. (1995) and Castro-Montoya et al. (2011). Many studies (Waghorn, 2008; Castro-Montoya et al., 2011; Supapong et al., 2017) indicated a reduction in acetate and an increment in propionate proportions as a result of CT effect on carbohydrates fermentation. In contrast, the findings of the present study revealed increases in both acetate and propionate proportions with Leucaena inclusion, which consequently increased C2/C3 ratio. In the same trend, an increase in acetic acid proportion was observed by Harun et al. (2017) when goats fed diet containing 25\% Leucaena leaves. The authors cleared that ruminal concentration of acetic 
acid is highly correlated with the structural carbohydrates amount, ruminal $\mathrm{pH}$, and microbial population that dominates in the rumen. Therefore, acetic acid production may be increased due to the improvement in NDF degradability with Leucaena. Another theory that explains the reason for high acetate with Leucaena inclusion is related to the presence of mimosine in Leucaena, which stimulates acetogenesis as a result of hydrogen accumulation that can be consumed by acetogens (Soltan et al., 2017). On the other hand, the increases in propionic acid production may be attributed to the increase in population number of Fibrobacter succinogenes, the main propionic-acid producer bacteria (Moss et al., 2000), or may be due to higher nitrogen solubility and nutrients availability for volatile fatty acids production with Leucaena (Phesatcha et al., 2013).

It has been indicated that isobutyrate production is correlated with protein degradation since dietary protein is the main source of branched-chain volatile fatty acids (Berthiaume et al., 2010). In harmony with the previous explanation, the current results concerning isobutyrate proportion were correlated to $\mathrm{NH}_{3}-\mathrm{N}$ concentrations that revealed higher values for alfalfa and grass hay than for Leucaena and rejected banana fruits.

\section{CONCLUSION}

Leucaena showed a potential feed resource for ruminant animals instead of alfalfa with higher protein level and promising phenolic components as well as low gas emission. Rejected banana fruits can be considered as a desirable energy source in animal feed with high degraded OM and a slow degradation rate of carbohydrates. The combination of Leucaena and rejected banana fruits is recommended to provide the required nutrients for ruminants in the arid and semiarid regions. Further studies should examine the effects of including Leucaena and rejected bananas in ruminant diets focusing on animal production, health, and final products (meat and milk).

\section{DECLARATIONS}

\section{Authors' contribution}

Dr. Mohamed Hanafy, Dr. Wafaa Ghoneem, and Dr. Harry Archimède, supervised the work, supported the experimental study, and reviewed the manuscript. Dr. Sobhy Sallam and Dr. Yosra Soltan supervised and carried out the in vitro part of the experiment. Dr. Mervat Youssef contributed to performing the chemical analysis. Dr. Mohamed Rashid contributed to the implementation of the research, results analysis, and the writing of the manuscript. All authors approved the final version of the manuscript.

\section{Competing interests}

The authors declare that they have no conflict of interest.

\section{Ethical consideration}

Ethical issues (including plagiarism, consent to publish, misconduct, data fabrication and/or falsification, double publication and/or submission, and redundancy) have been checked by all the authors.

\section{Acknowledgments}

The authors wish to acknowledge the support from INRAE, UR143, Unite de Recherches Zootechnique, Guadeloupe, France, and the Department of Animal and Fish Production, Alexandria University, Egypt.

\section{REFERENCES}

Aderao GN, Sahoo A, Bhatt RS, Kumawat PK, and Soni L (2018). In vitro rumen fermentation kinetics, metabolite production, methane and substrate degradability of polyphenol rich plant leaves and their component complete feed blocks. Journal of Animal Science and Technology, 60: 1-9. DOI: https://www.doi.org/10.1186/s40781-018-0184-6

Angarita E, Molina I, Villegas G, Mayorga O, Chará J, and Barahona R (2015). Quantitative analysis of rumen microbial populations by qPCR in heifers fed on Leucaena leucocephala in the Colombian Tropical Dry Forest Tropical Dry Forest. Acta Scientiarum. Animal Sciences, 37: 135142. DOI: https://www.doi.org/10.4025/actascianimsci.v37i2.24836

Association of official analytical chemists (AOAC) (2000). Official methods of analysis. Association of Analytical Communities, 1: 141-144. DOI: https://www.doi.org/10.1007/978-3-642-31241-0

Archimède H, González-García E, Despois P, Etienne T, and Alexandre G (2010). Substitution of corn and soybean with green banana fruits and Gliricidia sepium forage in sheep fed hay-based diets: Effects on intake, digestion and growth. Journal of Animal Physiology and Animal Nutrition, 94: 118-128. DOI: https://www.doi.org/10.1111/j.1439-0396.2008.00891.x

Archimède H, Rira M, Barde DJ, Labirin F, Marie-Magdeleine C, Calif B, Periacarpin F, Fleury J, Rochette Y, Morgavi DP et al. (2016). Potential of tannin-rich plants, Leucaena leucocephala, Glyricidia sepium and Manihot esculenta, to reduce enteric methane emissions in sheep. Journal of Animal Physiology and Animal Nutrition, 100: 1149-1158. DOI: https://www.doi.org/10.1111/jpn.12423

Babatunde GM (1992). Availability of banana and plantain products for animal feeding. Proceedings of the FAO Expert Consultation Held in CIA, 1991; Cali. Colombia, pp. 251-276. Available at: https://www.fao.org/3/t0554e/T0554E17.htm.

Bae J, Kim N, Shin Y, Kim SY, and Kim YJ (2020). Activity of catechins and their applications. Biomed. Dermatology, 4: 1-10. DOI: https://www.doi.org/10.1186/s41702-020-0057-8 
Berthiaume R, Benchaar C, Chaves AV, Tremblay GF, Castonguay Y, Bertrand A, Bélanger G, Michaud R, Lafrenière C, McAllister TA et al. (2010). Effects of nonstructural carbohydrate concentration in alfalfa on fermentation and microbial protein synthesis in continuous culture. Journal of Dairy Science, 93: 693-700. DOI: https://www.doi.org/10.3168/jds.2009-2399

Bhatta R, Saravanan M, Baruah L, and Sampath KT (2012). Nutrient content, in vitro ruminal fermentation characteristics and methane reduction potential of tropical tannin-containing leaves. Journal of the Science of Food and Agriculture, 92: 2929-2935. DOI: https://www.doi.org/10.1002/jsfa.5703

Bhatta R, Vaithiyanathan S, Shinde AK, and Jakhmola RC (2005). Effect of feeding complete feed block containing Prosopis cineraria leaves and polyethylene glycol (PEG)-6000 on nutrient intake, its utilization, rumen fermentation pattern and rumen enzyme profile in kids. Journal of the Science of Food and Agriculture, 85: 1788-1794. DOI: https://www.doi.org/10.1002/jsfa.2111

Bhatta R, Vaithiyanathan S, Singh NP, and Verma DL (2007). Effect of feeding complete diets containing graded levels of Prosopis cineraria leaves on feed intake, nutrient utilization and rumen fermentation in lambs and kids. Small Ruminant Research, 67: 75-83. DOI: https://www.doi.org/10.1016/j.smallrumres.2005.09.027

Blümmel M, Steinga $\beta$ H, and Becker K (1997). The relationship between in vitro gas production, in vitro microbial biomass yield and 15 N incorporation and its implications for the prediction of voluntary feed intake of roughages. British Journal of Nutrition, 77: 911-921. DOI: https://www.doi.org/10.1079/bjn19970089

Bueno ICS, Cabral Filho SLS, Gobbo SP, Louvandini H, Vitti DMSS, and Abdalla AL (2005). Influence of inoculum source in a gas production method. Animal Feed Science and Technology, 123: 95-105. DOI: https://www.doi.org/10.1016/j.anifeedsci.2005.05.003

Bueno ICS, Vitti DMSS, Louvandini H, and Abdalla AL (2008). A new approach for in vitro bioassay to measure tannin biological effects based on a gas production technique. Animal Feed Science and Technology, 141: 153-170. DOI: https://www.doi.org/10.1016/j.anifeedsci.2007.04.011

Castro-Montoya JM, Makkar HPS, and Becker K (2011). Chemical composition of rumen microbial fraction and fermentation parameters as affected by tannins and saponins using an in vitro rumen fermentation system. Canadian Journal of Animal Science, 91: 433-448. DOI: https://www.doi.org/10.4141/CJAS2010-028

Chaji M, Direkvandi E, and Salem AZM (2020). Ensiling of Conocarpus erectus tree leaves with molasses, exogenous enzyme and Lactobacillus plantarum impacts on ruminal sheep biogases production and fermentation. Agroforestry Systems, 94: 1611-1623. DOI: https://www.doi.org/10.1007/s10457-019-00436-X

Changxing L, Saeed M, Kamboh AA, Alagawany M, Abd El-Hack ME, Arain MA, Babazadeh D, Dhama K, and Chenling M (2018). Reconsidering a Citrus Flavonoid Naringin as a Promising Nutritional Supplement and Its Beneficial Health Applications in Humans, Animals and Poultry. International Journal of Pharmacology. https://doi.org/10.3923/ijp.2018

National Research Council (NRC) (2007). Nutrient requirements of small ruminants: Sheep, goats, cervids, and new world camelids. The National Academies Press, Washington, DC. DOI: https://www.doi.org/10.17226/11654

Erfle JD, Boila RJ, Teather RM, Mahadevan S, and Sauer FD (1982). Effect of pH on fermentation characteristics and protein degradation by rumen microorganisms in vitro. Journal of Dairy Science, 65: 1457-1464. DOI: https://www.doi.org/10.3168/jds.S0022-0302(82)82368-0

Francis G, Kerem Z, Makkar HPS, and Becker K (2002). The biological action of saponins in animal systems: A review. British Journal of Nutrition, 88: 587-605. DOI: https://www.doi.org/10.1079/bjn2002725

Getachew G, Makkar HPS, and Becker K (2000). Effect of polyethylene glycol on in vitro degradability of nitrogen and microbial protein synthesis from tannin-rich browse and herbaceous legumes. British Journal of Nutrition, 84: 73-83. DOI: https://www.doi.org/10.1017/s0007114500001252

Getachew G, Pittroff W, DePeters EJ, Putnam DH, Dandekar A, and Goyal S (2008a). Influence of tannic acid application on alfalfa hay: In vitro rumen fermentation, serum metabolites and nitrogen balance in sheep. Animal, 2: 381-390. DOI: https://www.doi.org/10.1017/S1751731107001486

Getachew G, Pittroff W, Putnam DH, Dandekar A, Goyal S, and DePeters EJ (2008b). The influence of addition of gallic acid, tannic acid, or quebracho tannins to alfalfa hay on in vitro rumen fermentation and microbial protein synthesis. Animal Feed Science and Technology, 140: 444 461. DOI: https://www.doi.org/10.1016/j.anifeedsci.2007.03.011

Goel G, and Makkar HPS (2012). Methane mitigation from ruminants using tannins and saponins. Tropical Animal Health and Production, 44: 729739. DOI: https://www.doi.org/10.1007/s11250-011-9966-2

Gomaa RMM, González-Ronquillo M, Arredondo-Ramos J, Castelán Ortega OA, and Molina LT (2017). Effect of tanniferous plants on in vitro digestion and methane production. Ecosistemas y Recur Agropecu, 4: 371. DOI: https://www.doi.org/10.19136/era.a4n11.1160

Hariadi BT, and Santoso B (2010). Evaluation of tropical plants containing tannin on in vitro methanogenesis and fermentation parameters using rumen fluid. Journal of the Science of Food and Agriculture, 90: 456-461. DOI: https://www.doi.org/10.1002/jsfa.3839

Harrison MT, McSweeney C, Tomkins NW, and Eckard RJ (2015). Improving greenhouse gas emissions intensities of subtropical and tropical beef farming systems using Leucaena leucocephala. Agroforestry Systems, 136: 138-146. DOI: https://www.doi.org/10.1016/j.agsy.2015.03.003

Hart KJ, Yáñez-Ruiz DR, Duval SM, McEwan NR, and Newbold CJ (2008). Plant extracts to manipulate rumen fermentation. Animal Feed Science and Technology, 147: 8-35. DOI: https://www.doi.org/10.1016/j.anifeedsci.2007.09.007

Harun NLA, Alimon AR, Jahromi MF, and Samsudin AA (2017). Effects of feeding goats with Leucaena leucocephala and Manihot esculenta leaves supplemented diets on rumen fermentation profiles, urinary purine derivatives and rumen microbial population. Journal of Applied Animal Research, 45: 409-416. DOI: https://www.doi.org/10.1080/09712119.2016.1205499

Huang Q, Liu X, Zhao G, Hu T, and Wang Y (2018). Potential and challenges of tannins as an alternative to in-feed antibiotics for farm animal production. Animal Nutrition, 4: 137-150. DOI: https://www.doi.org/10.1016/j.aninu.2017.09.004

Huang XD, Liang JB, Tan HY, Yahya R, Khamseekhiew B, and Ho YW (2010). Molecular weight and protein binding affinity of Leucaena condensed tannins and their effects on in vitro fermentation parameters. Animal Feed Science and Technology, 159: 81-87. DOI: https://www.doi.org/10.1016/j.anifeedsci.2010.05.008

Jayanegara A, Harahap RP, Ridla M, Laconi EB, and Nahrowi N (2018). Chemical composition and methane emission of some tropical forage legumes from Indonesia. American Institute of Physics (AIP) Conference Proceedings, volume 2021. DOI: https://www.doi.org/10.1063/1.5062752

Jones GA, McAllister TA, Muir AD, and Cheng KJ (1994). Effects of sainfoin (Onobrychis viciifolia Scop.) condensed tannins on growth and proteolysis by four strains of ruminal bacteria. Applied and Environmental Microbiology, 60: 1374-1378. DOI: https://www.doi.org/10.1128/aem.60.4.1374-1378.1994

Jouany JP (1994). Manipulation of microbial activity in the rumen. Archiv für Tierernaehrung, 46: 133-153. DOI: https://www.doi.org/10.1080/17450399409381766

Katoch R (2011). Analytical techniques in biochemistry and molecular biology. Springer New York, New York, NY, p. 448. DOI:

To cite this paper: Salama Rashid MR, Hanafy MA, Youssef MSH, Archimède H, Sallam SMA, Soltan YA, and Ali Ghoneem WM (2021). Chemical and in vitro evaluation of Leucaena (Leucaena leucocephala) Leaves as a Substitute of Alfalfa (Medicago sativa L.) with/without Rejected Green Banana Fruits (Musa paradisiaca). World Vet. J., 11 (4): 678-697. DOI: https://dx.doi.org/10.54203/scil.2021.wvj86 
Konitzer K, and Voigt S (1963). Determination of Ammonium in Blood and Tissue Extracts. Clinica Chimica Acta, 8: 5-11. DOI: https://www.doi.org/10.1016/0009-8981(63)90192-X

Kramer K (2014). Banana foliage and rejected banana fruits as feed for livestock in Hawai'i. Animal Science 321, University of Hawaii, Hohonu, 12: $17-20$ Available https://hilo.hawaii.edu/campuscenter/hohonu/volumes/documents/BananaFoliageandRejectedBananaFruitsasFeedforLivestockinHawaiiKuileiKra mer.pdf

Makkar HPS (1993). Antinutritional factors in foods for livestock. BSAP Occasional Publication, 16: 69-85. DOI: https://www.doi.org/10.1017/s0263967x00031086

Makkar HPS (2002). Applications of the in vitro gas method in the evaluation of feed resources, and enhancement of nutritional value of tannin-rich tree/browse leaves and agro-industrial by-products. Animal Production and Health Section, International Atomic Energy Agency, Vienna (Austria), 169: 23-40. Available at: https://inis.iaea.org/search/search.aspx?orig_q=RN:33032969

Makkar HPS (2003). Effects and fate of tannins in ruminant animals, adaptation to tannins, and strategies to overcome detrimental effects of feeding tannin-rich feeds. Small Ruminant Research, 49: 241-256. DOI: https://www.doi.org/10.1016/S0921-4488(03)00142-1

Makkar HPS, Becker K, Abel H, and Szegletti C (1995). Degradation of condensed tannins by rumen microbes exposed to quebracho tannins (QT) in rumen simulation technique (RUSITEC) and effects of QT on fermentative processes in the RUSITEC. Journal of the Science of Food and Agriculture, 69: 495-500. DOI: https://www.doi.org/10.1002/jsfa.2740690414

McSweeney CS, Palmer B, Bunch R, and Krause DO (1999). Isolation and characterization of proteolytic ruminal bacteria from sheep and goats fed the tannin-containing shrub legume Calliandra calothyrsus. Applied and Environmental Microbiology, 65: 3075-3083. DOI https://www.doi.org/10.1128/aem.65.7.3075-3083.1999

McSweeney CS, Palmer B, McNeill DM, and Krause DO (2001). Microbial interactions with tannins: Nutritional consequences for ruminants. Animal Feed Science and Technology, 91: 83-93. DOI: https://www.doi.org/10.1016/S0377-8401(01)00232-2

Mohammadabadi T, and Jolazadeh A (2017). Replacement of alfalfa hay (Medicago sativa L.) with subabul (Leucaena leucocephala) leaf meal in diets of Najdi goats: Effect on digestion activity of rumen microorganisms. Tropical Animal Health and Production, 49: 1309-1316. DOI: https://www.doi.org/10.1007/s11250-017-1330-8

Montoya-Flores MD, Molina-Botero IC, Arango J, Romano-Muñoz JL, Solorio-Sánchez FJ, Aguilar-Pérez CF, and Ku-Vera JC (2020). Effect of dried leaves of leucaena leucocephala on rumen fermentation, rumen microbial population, and enteric methane production in crossbred heifers. Animals, 10: 1-17. DOI: https://www.doi.org/10.3390/ani10020300

Morales R, and Ungerfeld EM (2015). Use of tannins to improve fatty acids profile of meat and milk quality in ruminants: A review. Chilean Journal of Agricultural Research, 75: 239-248. DOI: https://www.doi.org/10.4067/S0718-58392015000200014

Moss AR, Jouany JP, and Newbold J (2000). Methane production by ruminants: Its contribution to global warming. Animal Research, 49: 231-253. DOI: https://www.doi.org/10.1051/animres:2000119

Murdiati TB, McSweeney CS, and Lowry JB (1992). Metabolism in sheep of gallic acid, tannic acid and hydrolysable tannin from Terminalia oblongata. Australian Journal of Agricultural Research, 43: 1307-1319. DOI: https://www.doi.org/10.1071/AR9921307

Noviandi CT, Kustaantinah K, Irawan A, Widyobroto BP, and Astuti A (2021). Determination of in vitro gas production kinetics by adding Leucaena leucecophala and corn oil to the ration in different ratios. Iranian Journal of Applied Animal Science, 11: 23-31. Available at: http://ijas.iaurasht.ac.ir/article 680281.html

Onodera R, and Henderson C (1980). Growth factors of bacterial origin for the culture of the rumen oligotrich protozoon, entodinium caudatum. Journal of Applied Bacteriology, 48: 125-134. DOI: https://www.doi.org/10.1111/j.1365-2672.1980.tb05214.x

Pal K, Patra AK, and Sahoo A (2015). Evaluation of feeds from tropical origin for in vitro methane production potential and rumen fermentation in vitro. Spanish Journal of Agricultural Research, 13(3): e0608. DOI: https://www.doi.org/10.5424/sjar/2015133-7467

Palmquist DL, and Conrad HR (1971). Origin of plasma fatty acids in lactating cows fed high grain or high fat diets. Journal of Dairy Science, 54: 1025-1033. DOI: https://www.doi.org/10.3168/jds.S0022-0302(71)85966-0

Patra AK, and Saxena J (2011). Exploitation of dietary tannins to improve rumen metabolism and ruminant nutrition. Journal of the Science of Food and Agriculture, 91: 24-37. DOI: https://www.doi.org/10.1002/jsfa.4152

Patra AK, and Saxena J (2009). Dietary phytochemicals as rumen modifiers: A review of the effects on microbial populations. Antonie van Leeuwenhoek, 96: 363-375. DOI: https://www.doi.org/10.1007/s10482-009-9364-1

Phesatcha K, Wanapat M, and Mcsweeney C (2013). Effect of dried Leucaena leaf supplementation on rumen ecology, nutrient digestibility and urinary excretion of 2,3-dihydroxy pyridone (2,3-DHP) and 3,4-dihydroxy pyridone (3,4-DHP) in swamp buffaloes. Buffalo Bull, 32: 975-979. Available at: https://ibic.lib.ku.ac.th/e-Bulletin/IBBUSI201302161.pdf

Pieltain MC, Castañón JIR, Ventura MR, and Flores MP (1998). Nutritive value of banana (Musa acuminata L.) fruits for ruminants. Animal Feed Science and Technology, 73: 187-191. DOI: https://www.doi.org/10.1016/s0377-8401(98)00134-5

Piñeiro-Vázquez AT, Canul-Solis JR, Jiménez-Ferrer GO, Alayón-Gamboa JA, Chay-Canul AJ, Ayala-Burgos AJ, Aguilar-Pérez CF, and Ku-Vera JC (2018). Effect of condensed tannins from Leucaena leucocephala on rumen fermentation, methane production and population of rumen protozoa in heifers fed low-quality forage. Asian-Australasian Journal of Animal Sciences, 31: 1738-1746. DOI: https://www.doi.org/10.5713/ajas.17.0192

Rashid MR, Hanafy MA, Ghoneem WM, Jean Bart M, and Archimède H (2019). Response of lactating Blackbelly ewes to feed: Leucaena leucocephala leaves or alfalfa with/without green banana fruits, in: Energy and Protein Metabolism and Nutrition. Wageningen Academic Publishers, Netherlands, pp. 245-246. DOI: https://www.doi.org/10.3920/978-90-8686-891-9 57

Rira M, Morgavi DP, Archimède H, Marie-Magdeleine C, Popova M, Bousseboua H, and Doreau M (2015). Potential of tannin-rich plants for modulating ruminal microbes and ruminal fermentation in sheep. Journal of Animal Science, 93: 334-347. DOI: https://www.doi.org/10.2527/jas.2014-7961

Rodríguez R, Frutos P, and Fondevila M (2015). A new index to estimate reactivity and biological effect of tannins, using tropical browse legumes as a model. Animal Feed Science and Technology, 205: 42-48. DOI: https://www.doi.org/10.1016/j.anifeedsci.2015.04.007

Sabry M, Nasserz MEA, Kamel HEM, Abaza MA, and Soltan YA (2021). Effect of replacing corn grains with date palm kernels on ruminal fermentation, feed degradability, and methane production under different initial in vitro $\mathrm{pH}$ conditions. Animal Biotechnology, pp. 1-12. DOI: https://www.doi.org/10.1080/10495398.2021.1886941

Salama HSA, El-Zaiat HM, Sallam SMA, and Soltan YA (2020). Agronomic and qualitative characterization of multi-cut berseem clover (Trifolium alexandrinum L.) cultivars. Journal of the Science of Food and Agriculture, 100: 3857-3865. DOI: https://www.doi.org/10.1002/jsfa.10424

Sallam SMA, Bueno ICS, Godoy PB, Nozella EF, Vitti DMSS, and Abdalla AL (2010). Ruminal fermentation and tannins bioactivity of some browses using a semi-automated gas production technique. Tropical and Subtropical Agroecosystems, 12: 1-10. Available at:

To cite this paper: Salama Rashid MR, Hanafy MA, Youssef MSH, Archimède H, Sallam SMA, Soltan YA, and Ali Ghoneem WM (2021). Chemical and in vitro evaluation of Leucaena (Leucaena leucocephala) Leaves as a Substitute of Alfalfa (Medicago sativa L.) with/without Rejected Green Banana Fruits (Musa paradisiaca). World Vet. J., 11 (4): 678-697. DOI: https://dx.doi.org/10.54203/scil.2021.wvj86 
Saminathan M, Sieo CC, Gan HM, Abdullah N, Wong CMVL, and Ho YW (2016). Effects of condensed tannin fractions of different molecular weights on population and diversity of bovine rumen methanogenic archaea in vitro, as determined by high-throughput sequencing. Animal Feed Science and Technology, 216: 146-160. DOI: https://www.doi.org/10.1016/j.anifeedsci.2016.04.005

Statistical Analysis System (SAS) (2015). SAS® OnDemand for Academics: User’s Guide 524. Statistical Analysis System Institute Inc.

Schulmeister TM, Ruiz-Moreno M, Benitez J, Ponce CH, Lamb GC, and DiLorenzo N (2020). Potential of cull banana fruit at two maturity stages as a feed supplement for cattle: Effects on in vitro ruminal fermentation, kinetics of gas production and digestibility. Waste and Biomass Valorization, 11: 6689-6695. DOI: https://www.doi.org/10.1007/s12649-019-00883-8

Serra V, Salvatori G, and Pastorelli G (2021). Dietary polyphenol supplementation in food producing animals: Effects on the quality of derived products. Animals, 11: 1-44. DOI: https://www.doi.org/10.3390/ani11020401

Shakeel S, Rehman MU, Tabassum N, Amin U, and Mir M (2017). Effect of naringenin (A naturally occurring flavanone) against pilocarpine-induced status epilepticus and oxidative stress in mice. Pharmacognosy Magazine, 13: 154-160. DOI: https://www.doi.org/10.4103/0973-1296.203977

Sidhu JS, and Zafar TA (2018). Bioactive compounds in banana fruits and their health benefits. Food Quality and Safety, 2: 183-188. DOI: https://www.doi.org/10.1093/fqsafe/fyy019

Singleton VL (1981). Naturally occurring food toxicants: Phenolic substances of plant origin common in foods. Advances in Food Research, 27: 149242. DOI: https://www.doi.org/10.1016/S0065-2628(08)60299-2

Soltan YA, Hashem NM, Morsy AS, El-Azrak KM, El-Din AN, and Sallam SM (2018). Comparative effects of Moringa oleifera root bark and monensin supplementations on ruminal fermentation, nutrient digestibility and growth performance of growing lambs. Animal Feed Science and Technology, 235: 189-201. DOI: https://www.doi.org/10.1016/j.anifeedsci.2017.11.021

Soltan YA, Morsy AS, Lucas RC, Abdalla AL (2017). Potential of mimosine of Leucaena leucocephala for modulating ruminal nutrient degradability and methanogenesis. Animal Feed Science and Technology, 223: 30-41. DOI: https://www.doi.org/10.1016/j.anifeedsci.2016.11.003

Soltan YA, Morsy AS, Sallam SMA, Louvandini H, and Abdalla AL (2012). Comparative in vitro evaluation of forage legumes (prosopis, acacia, atriplex, and leucaena) on ruminal fermentation and methanogenesis. Animal Feed Science and Technology, 21: 759-772. DOI: https://www.doi.org/10.22358/jafs/66148/2012

Soltan YA, Morsy AS Sallam SMA, Lucas RC, Louvandini H, Kreuzer M, and Abdalla AL (2013). Contribution of condensed tannins and mimosine to the methane mitigation caused by feeding Leucaena leucocephala. Archives of Animal Nutrition, 67: 169-184. DOI: https://www.doi.org/10.1080/1745039X.2013.801139

Steel RGD, and Torrie JH (1980). Principles and procedures of statistics: A Biometrical Approach., $2^{\text {nd }}$ edition. McGraw-Hill Book Company, p. 859.

Supapong C, Cherdthong A, Seankamsorn A, Khonkhaeng B, Wanapat M, Uriyapongson S, Gunun N, Gunun P, Chanjula P, and Polyorach S (2017). In vitro fermentation, digestibility and methane production as influenced by Delonix regia seed meal containing tannins and saponins. Animal Feed Science and Technology, 26: 123-130. DOI: https://www.doi.org/10.22358/jafs/73890/2017

Szumacher-Strabel M, and Cieślak A (2010). Potential of phytofactors to mitigate rumen ammonia and methane production. Animal Feed Science and Technology, 19: 319-337. DOI: https://www.doi.org/10.22358/jafs/66296/2010

Taghizadeh A, Palangi V, and Safamehr A (2008). Determining nutritive values of alfalfa cuts using in situ and gas production techniques. American Journal of Animal and Veterinary Sciences, 3: 85-89. Available at: https://thescipub.com/pdf/ajavsp.2008.85.89.pdf

Tan HY, Sieo CC Abdullah N, Liang JB, Huang XD, and Ho YW (2011). Effects of condensed tannins from Leucaena on methane production, rumen fermentation and populations of methanogens and protozoa in vitro. Animal Feed Science and Technology, 169: 185-193. DOI: https://www.doi.org/10.1016/j.anifeedsci.2011.07.004

Tavendale MH, Meagher LP, Pacheco D, Walker N, Attwood GT, and Sivakumaran S (2005). Methane production from in vitro rumen incubations with Lotus pedunculatus and Medicago sativa, and effects of extractable condensed tannin fractions on methanogenesis. Animal Feed Science and Technology, 123-124: 403-419. DOI: https://www.doi.org/10.1016/j.anifeedsci.2005.04.037

Theodoridou K, Aufrère J, Andueza D, Pourrat J, Le Morvan A, Stringano E, Mueller-Harvey I, and Baumont R (2010). Effects of condensed tannins in fresh sainfoin (Onobrychis viciifolia) on in vivo and in situ digestion in sheep. Animal Feed Science and Technology, 160: 23-38. DOI: https://www.doi.org/10.1016/j.anifeedsci.2010.06.007

Ultee A, Bennik MHJ, and Moezelaar R (2002). The phenolic hydroxyl group of carvacrol is essential for action against the food-borne pathogen Bacillus cereus. Applied and Environmental Microbiology, 68: 1561-1568. DOI: https://www.doi.org/10.1128/AEM.68.4.1561-1568.2002

Waghorn G (2008). Beneficial and detrimental effects of dietary condensed tannins for sustainable sheep and goat production-Progress and challenges. Animal Feed Science and Technology, 147: 116-139. DOI: https://www.doi.org/10.1016/j.anifeedsci.2007.09.013

Waghorn GC, Ulyatt MJ, John A, and Fisher MT (1987). The effect of condensed tannins on the site of digestion of amino acids and other nutrients in sheep fed on Lotus corniculatus L. British Journal of Nutrition, 57: 115-126. DOI: https://www.doi.org/10.1079/bjn19870015

Wallace RJ, Rooke JA, McKain N, Duthie CA, Hyslop JJ, Ross DW, Waterhouse A, Watson M, and Roehe R (2015). The rumen microbial metagenome associated with high methane production in cattle. BMC Genomics, 16: 1-14. DOI: https://www.doi.org/10.1186/s12864-015-2032$\underline{0}$

Xu Y, Tao Z, Jin Y, Yuan Y, Dong TTX, Tsim KWK, and Zhou Z (2018). Flavonoids, a potential new insight of leucaena leucocephala foliage in ruminant health. Journal of Agricultural and Food Chemistry, 66: 7616-7626. DOI: https://www.doi.org/10.1021/acs.jafc.8b02739

Yan Y, Zhou X, Guo K, Zhou F, and Yang H (2020). Use of chlorogenic acid against diabetes mellitus and its complications. Journal of Immunology Research, pp. 1-6. DOI: https://www.doi.org/10.1155/2020/9680508

Yang K, Zhang L, Liao P, Xiao Z, Zhang F, Sindaye D, Xin Z, Tan C, Deng J, Yin Y, and Deng B (2020). Impact of gallic acid on gut health: focus on the gut microbiome, immune response, and mechanisms of action. Frontiers in Immunology, 11: 1-13. DOI: https://www.doi.org/10.3389/fimmu.2020.580208 